\title{
Fundamental Human Rights Violations in European Union: An Overview
}

\author{
Dr. Muhammad Arif Khan \\ Ph.D from School of International and Public Affairs \\ Jilin University \\ P.R. China \\ Arifkhan756@hotmail.com \\ Dr. Rizwana Jabeen \\ Assistant Professor \\ Department of International Relations \\ FUUAST, Karachi - Pakistan \\ rizjab2003@hotmail.com \\ Safia A. Khan \\ Research Scholar at School of International and Public Affairs \\ Jilin University \\ P.R. China \\ Ksafia957@gmail.com
}

\begin{abstract}
This research piece is written on "Globalization and Fundamental Human Rights Violations in Europe". It deals with very important issue of Human rights, violation being carried out in different kinds of its nature such as forcefully deport of immigrants from different European countries as like Italy, Greece. Moreover, a burning issue prevailing in most of the European countries in the recent times is the issue of wearing Hijab which means covering of Muslim women face with veil which is in most of the cases intolerable in European society. The significance of this topic stems from the fact that European continent was given Nobel Prize for peace in 2012 and keeping an eye that ward, Europe was supposed to be ideal continent for its inhabitants, but unfortunately for the last several years incidents of human rights violations are being noticed by
\end{abstract}






Keywords: Women, Hijab, Europe, Human Rights, Violations, Justice.

\section{Introduction}

Human rights violation in Europe is not just an issue of current days but it has a long history in Europe. If we peep in the history of last twenty years of European countries from Bosnia, Herzegovina to Greece, we observe the numbers of incidents of human rights violations took place in different European countries. The world witnessed different aspects of human rights violations in Europe such as the genocide of Muslims in Bosnia and Herzegovinian from 1992 to 1995.Though European continents is considered the most civilized and most privileged continent of the world, and won the 2012 Nobel peace prize of its renovation "to a continent of peace from a continent of war", However Europe is not in a sense perfect continent in terms of human rights, and human rights violation still plague the continent by looking at the other facets of the human rights violations in European countries is current critical issue of Muslim women of France, Germany, Austria and UK are being attacked and humiliated for wearing Hijab.

Hijab is a religious identity of Muslim women all over the world by which they cover their head and some part of the face so that they can be identified as Muslims. Another issue of human rights violation in Europe is discriminationagainst the Muslims and the Sikhs.

The deportations of Syrian emigrantsby the Greek government to Europe's most troubled country, after a major swipe in August 2017, resulted in the search for 6,000 undocumented immigrants, 1,500 of whom were arrested 


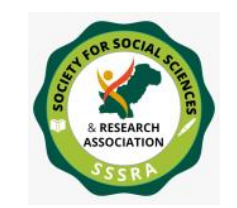

and sent to prison. According to Amnesty International (2011), has described Greece's expulsion tactics as deeply alarming (Triandafyllidou, 2017).

\section{Human Rights Violations in France:}

The French Republic is a multi-religious country in Europe, where people from different parts of the world live better and earn a living. For quite a while now, French legislative issues have been shaken by the matter of the Roma and demolishing their camps all through France has had rights gatherings, equipped since President Sarkozy declared that he would take measures to smother the Roma people group in 2008. His successor, Francois Holland, did not change the administration's strategy towards the Roma and kept on disassembling the camps and persuasively resettle the Roma in their nation of inception (Vigoureux, 2016, November 4).

A Catholic Bishop named Jacques Gaillot talked it was "dishonourable " to tidy up the camps. "On the off chance that you need to toss individuals out, you have to recognize what you will do with them". He talked about very nearly 15,000 Roma living in France. This was not the situation here. It is a pity that According Amnesty International (2001), has requested that France reassess its arrangement, however, there has been no adjustment in the organization. "We have not seen an unmistakable duty from the legislature to put a conclusion to constrained expulsions and guarantee that arrangements are actualized" bind that regards and secures France's lodging rights must carry its national enctment into line with global commitments. Until the point when the important advances are embraced, the ejections of the Roma people group will continue, said in an announcement (Martin, 2013)

Only seven days back, Marseilles stepped up with regards to oust around 50 Roma from their camp before they set it ablaze.

\section{Human Rights Abuses in the United Kingdom}




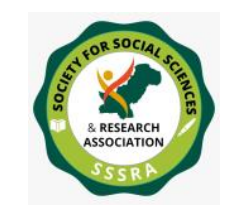

The UK names itself as the father of the vote based system and the safeguard of human rights. In any case, in spite of the 2004 decision that confinement for an uncertain period was in opposition to the European Convention on Human Rights, the United Kingdom kept Julian Assange, organizer of WikiLeaks, in detainment for very nearly 700 days without charge (of which 115 days were covered up in the Ecuadorian government office, which can't leave the nation). In spite of the fact that Assange was blamed for psychological oppression, the United Kingdom couldn't confine him for over 14 days without being accused of a wrongdoing.

The administration additionally undermined, and afterwards pulled back from, the remarkable infringement of the Vienna Convention by saying that it was ambushing a consulate to capture Assange, who was humiliated by every one of the gatherings included, Ecuadorian Foreign Minister Ricardo Patino calledin June 2015, the dangers 'an improper majority rule, non-military personnel and legislative nation'. In the meantime, the fan is as yet adapting to the circumstance of Assange, in light of the fact that feelings of trepidation of being removed to Sweden will take him to the United States, where he will absolutely need to endure the cost of fleeing (Ouald Chaib, 2013).

Thousands of UK Citizens swept up In Immigration Spot Checks: -

The Home Office UK is blamed by human rights legal advisors in 2010 for "racial profiling", which must be inspected. English MPs and human rights legal counsellors utilize the landing page administration to research how movement authorities do on-the-spot checks after the information shows that they utilize a 'racial profile'. Bristol Cable got new information from its home office from a participation office with a media helpful. Information demonstrates that over the most recent five years, in excess of 19,000 British nativesfor every 102,552 occupants have been liable to movement controls, with very nearly one of every five human rights legal counsellors expressing that this high level of British residents shows that "controls depend on racial profiles". Stella Creasy MEP,who had beforehand raised the issuein 2015of air strikes in her voting public, approaches the Interior Ministry to "address networks like mine as an issue 


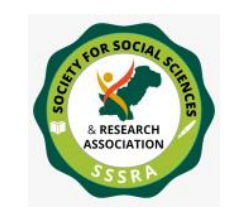

of direness", is likewise not clever (The Bureau of Investigative Journalism, 2017, October 9).

Scope from January 2012 to January 2017 was acquired by the Bristol link and tried by the Bureau. The Ministry of the Interior has dependably demanded that authorities talk with individuals not based on "ethnicity" but rather based on "knowledge". In any case, given that just about one of every five of them is a British resident, human rights legal counsellors have requested this supposition. They stretch that 'these individuals being by definition British, any data utilized for on-the-spot checks must be absolutely off-base'.

This date incorporates the 11 biggest urban areas in Wales, Scotland and England. It records your nationality when you are confined by movement authorities in these urban areas. In London alone, somewhere in the range of 8002 British nationals captured in Glasgow and Sheffield.

Different gatherings have additionally raised concerns a previous instructor Frances Webber who currently serves in the Institute for racial connections as the appointee seat, stated, "It isn't sufficient for the Home office just to deny that racial profiling happens given the proof of the ponderous stops of (Black and minority) Britons at tube stations, The Home office needs to exhibit that its training has changed.

- Ferocity against Females in the UK: -

Ferocity against females has been an alarming problem in Britain these days. In December2014,theHouse of Common voted to endorse the Council of Europe Convention on the Representation and Punishment of Violence against Women and Domestic Violence. In July 2015,the UN Committee on the Rights of the Child recommended better information collection on violence against females and children, including genderbased violence and domestic violence.

Grave worries endure on the decrease in funds for specialized facilities for females who have been victims of violence or domestic violence. Studies on local females have shown that two out of three survivors must be 


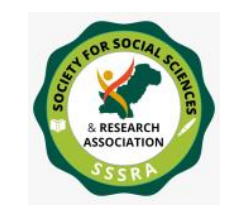

placed in shelters because of a lack or their inability to meet their needs and that the proportion of women and girls belonging to ethnic minorities is four out of five. These are therefore signs of human rights violations in this part of Europe (Brunsdon, 2005).

\section{European Court of Justice Banned Muslim Women's Headscarf (Veil): -}

Another demonstration of human rights violation in Europe occurred, when the European Court of Justice passed a rulingin March 2017saying, "as part of general policy garment can be barred that showcase political and religious symbols."

Right-wing European politicians have welcomed the ECJ ruling, which allows corporations to prohibit workers from putting on visible religious symbols, as a long-awaited ruling implemented during the Dutch and French campaigns of elections. In its first decision on the wearing of the Islamic headscarf at work, the EU Court in Luxembourg ruledin 2017 that such clothing may be banned, but only all religious and political symbols as part of a general policy.

Customers can also not demand that employees remove the fabric if the company does not have a policy prohibiting religious symbols, as the court ruled. On the eve of a controversial issue, a long-awaited verdict was rendered. In France, where the race for President François Holland's successor is still open, right-wing politicians have addressed this issue. François Fillon, presidential candidate of 2017,firmly attached to the place of Islam in France, welcomes this verdict. When opening the formal investigation procedure into the misuse of public funds, he said in a statement that "this is a great relief, not only for thousands of companies but also for their employees" (Perlez, 2007, June 22).

Gilbert Collard, an MP for the Rassemblement Bleu Marine which supports Marine Le Pen'sFront National, claimed the ruling was an endorsement. "Even the ECJ rates Marine he wrote on Twitter. 


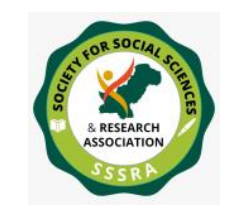

Thus, there is an anxiety in Muslims living across Europe regarding their rights are being violated by not only the European Society, but EU court of Justice as well.

\section{Basic Human Rights in Germany and Belgium:}

Germany is the same as other European nations as far as human rights infringement. Burka bans the utilization of headscarves and hinders the authoritative timetable in Europe. In Germany, a conservative populist party, as a contrasting option to Germany, likewise respected the decision of European Court of Justice administering sends the correct flag, especially for

Germany. George Pazderski, chief of the AFD Party, talked about it in 2017.

In these cases, the European Court of Justice mutually censured two French and Belgian ladies, who had been discharged for declining to expel the cover: "The inside guideline of society precludes the noticeable utilization of political methods of insight. The Court of First Instance has expressed this. George Pazderski considers that society's craving to keep up an impartial picture is true blue and allowed by national laws denying political, philosophical or religious images (Yigit, 2012).

The primary case has been alluded to the European Court of Justice by a Belgian court. Samira Achbita was an assistant for the Belgian organization $\mathrm{G} 4 \mathrm{~S}$, an outsourcing and security organization recorded on the London Stock Exchange when following three long stretches of work she chose to wear the cover to work for religious reasons. Achbita was discharged in June 2006 for declining to evacuate her shroud. The organization has pronounced that it is abusing an unwritten strategy that forbids religious images.

Micropole configuration design Asma Bougnaoui was terminated after the customer whined that his representatives were "humiliated" by the cloak when he was in the workplace giving guidance in the second case. Before 




Pak. Journal of Int'L Affairs, Vol 3, Issue 2 (2020)

Fundamental Human Rights Violations...

taking office, he was informed that wearing a shroud could be an issue for the organization's clients (Zick, 2012, p.45).

\section{Senior EU lawyer backs "Discriminatory" workplace ban on Muslim women's headscarves:}

On account of the Belgian subject Samira in 2017, the Court of Justice took after the counsel of the abnormal state legitimate counsellor, who expressed that organizations ought to have the capacity to restrict the utilization of religious and political images. "The Court takes note of that the G4S Rules of Procedure concern the show of any noticeable indication of political, philosophical or religious conviction, without refinement. This arrangement, consequently, treats all representatives in an organization similarly, specifically by obliging them to be impartial when all is said in done and without qualification of any sort.

In the Asma Bougnaoui case in 2017, the court's legitimate insight considered that she had been oppressed. She was "professionally capable" and was expelled simply because she declined to evacuate her cover, as suggested by the Advocate General. The Court affirmed this point with a less persuading affirmation. The customer's longing not to be dealt with by a specialist with a headscarf has not given organizations the chance to bypass EU against separation enactment.

"In any case, without such an arrangement, the readiness of the business to fulfil the customer's ability to stop the arrangement of administrations to the business by a worker wearing an Islamic cloak can't be viewed as a work prerequisite which could bar separation.

The Court of Justice did not administer on the rejection of Asma on the ground that it had not consented to the organization's strategy since the issue fell inside the purview of the French court. The choice upheld the AFD arrangement of George Pazderski. The German daily paper Suddentsche Zeitung anticipated that this choice would fundamentally adjust the German court's evaluation of comparable cases since it had been expected since 2002 that religious images must be prohibited in the work environment for wellbeing reasons (McGoldrick, 2006, p.173). 


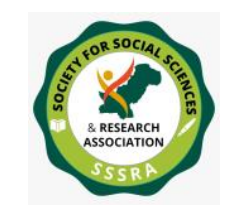

\section{A ruling from ECHR that allowed crosses to be worn:}

This decision mirrors a logical inconsistency in the European Court of Justice enactment on Muslims. A judgment that goes past a straightforward boycott can prompt mistaken assumptions about religious images that can be worn in the working environment. Some lawful specialists have expressed this appears to confine the European Court of Human Rights (ECHR) administering enabling Christian crosses to be worn.

Steve Peers, Professor of European Union Law at the University of Essex, said that the ongoing choice of the European Court of Justice is unfortunate when it restricts the choice of the European Court of Human Rights that wearing a religious image "is in some cases the privilege of a specialist to show his flexibility of religion" (Council of Europe \& European Court of Human Rights. 2011).

It reasoned that the Court of Justice had not managed this case law or with the qualification between religious opportunity and non-separation. The ECHR is the Supreme Court of the 47 individuals from the Council of Europe and isn't a piece of the European Union. Generally, the EU Court of Justice in Luxembourg has restricted itself to make up for contortions in the European interior market, however, its purview has extended with the expansion of Community law ( Nisar, 2006, p.5).

This decision drove the religious gathering to acknowledge with terrify the Conference of European Rabbis, which incorporates 700 Jewish pioneers all through Europe, and to state that Europe would send an unmistakable flag that its religious networks were never again welcome (Council of Europe, 2013).

\section{Discrimination against Muslim Women: -}

Maryam H'madoun of the Open Society Justice Initiative said she was baffled with the decision, which she portrayed as victimization Muslim ladies who chose to demonstrate their religion in their garments. "This will 


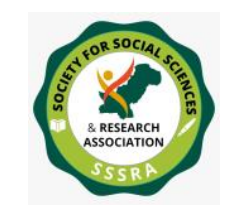

victimize Muslim ladies in the working environment, yet in addition against Jewish men conveying crosses. This applies to every single Muslim lady, however lopsidedly.

She said that Stephen Evans, executive of the battle of the National Lay Society in the UK, stated: "When the restriction on labourers who are religiously or politically nonpartisan and this rule applies similarly to all, it is unlikely to state that it is less good. "Religious and political lack of bias is a phenomenal avocation, and when organizations and associations like to introduce themselves in as such, the choice demonstrates that this approach is completely in accordance with uniformity and human rights. This proves that human right is being violated in ECHR's ruling (Emmanuel Tawil, 2005).

\section{Human Rights Violations in Greece: -}

In Athens, the choice of the Greek Supreme Administrative Court from 22 to 20 September 2014to remove two Syrian refuge seekerrs to Turkey since Turkey is a protected third nation which represents a danger to "Greece", said Eva Cosse, a Greek analyst gaining practical experience in human rights checking.

"In spite of the way that Turkey does not allow Syrians and other shelter searchers in Turkey full rights to be mistreated as displaced people, and regardless of the snags, they look in getting to instruction and other fundamental administrations, the court has given the thumbs up for the arrival of two Syrians without first inspecting their haven application (Amnesty International, 2011).

The case was consulted in the structure of an understanding between the European Union and Turkey in March 2016, which means to repatriate the lion's share of haven searchers from the Greek island to Turkey without inspecting their shelter application.

The agreement depends on the wrong introduce that Turkey is a sheltered third nation for haven searchers. Under this agreement, Turkey will get 


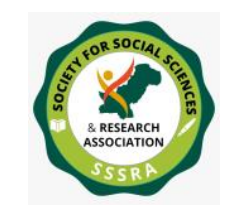

billions of euros in help, visa advancement for Turkey will get billions of euros in help, visa progression for Turkish residents and the resumption of transactions on Turkey's promotion to the EU (European Comission, 2016, March 19).

\section{- Deplorable and Volatile Conditions on Greek Island: -}

Up until now, no refuge searcher has been persuasively repatriated to Turkey under the EU-Turkey Agreement without first looking at the determination of his shelter application. Be that as it may, 1,200 people were extradited to Turkey after their applications had been dismissed on substantive grounds or in light of the fact that they had neither connected for shelter nor pronounced their ability to return deliberately.

EU haven law enables EU governments to send shelter searchers to a "sheltered third nation" without looking at their refuge application if the nation regards exile rights gauges just in the event that it regards the standards of non-refoulement, which incorporate people, who are not removed or come back to a nation where they would be in danger of torment and coldblooded or debasing treatment or of being debilitated in their life and freedom, and where a haven searcher can apply for refuge and appreciate any security offered by the 1951 Convention identifying with the Status of Refugees, in the event that he/she has been perceived as a displaced person (European Centre for Disease Prevention and Control, 2011).

Turkey keeps up the land furthest reaches of its interest in the evacuee status change process, which avoids non-European people from displaced person status.

Syrian displaced people living in Turkey under transitory security have official access to free human services, two million Syrian exiles living outside outcast camps in Turkey are attempting to discover asylum and a large number of them are living in target verse. 


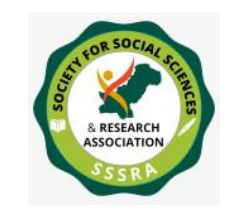

As indicated by the most recent accessible information, in excess of 300,000 Syrian youngsters have not gone to class since they work for their families, can't bear to transport or deal with their families, have no methods for transport or school materials, or for different reasons, for example, harassing at school. Non-Syrian haven searchers in Turkey, including Afghans and Iraqis, are not qualified for impermanent security or essential state administrations (Ouald Chaib, 2013).

Under EU rules, Turkey can't be viewed as a protected third nation for Syrian and different displaced people," said Cossa. "It is exceptionally frustrating that the Greek court has embraced the EU's rash approach, which clarifies why the displaced person circumstance on the Greek island is woeful and unsteady.

\section{Torture and other ill-treatment in Europe: -}

The Office has not yet successfully researched assertions of police abuse and has not set up an autonomous dissensions instrument in connection to these claims. The administrations of North Rhine-Westphalia and SaxonyAnhalt have wanted to acquaint a commitment with recognizing cops on obligation toward the finish of the year.

The German instrument for the counteractive action of torment accommodated in the Optional Protocol to the United Nations Convention against Torture still needed adequate human and budgetary assets. In April, prosecutors finished an overview of two Afghan and Moroccan evacuees in care at the local police headquarters in Hanover in 2014.

In September, a German locale court rejected one of the victims' solicitations to rethink the case. These torture and ill-treatment stains are defaming the Europe civilized and well-behaved society that is more educated than any other part of the world (Mühe, 2011, p.18).

\section{Racial Discrimination in Europe: - Germany}




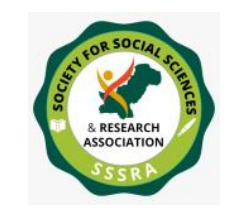

In October 2015, the German Bundestag set up a second board of trustees of request to research deficiencies in the examination of rehashed and xenophobic wrongdoings conferred by extraordinary conservative National Socialists against individuals from ethnic minorities somewhere in the range of 2000 and 2007.

In spite of the proposals of the United Nations Committee on the Elimination of Racial Discrimination and the Council of Europe Commissioner for Human Rights, no formal examination has been propelled into the conceivable part of institutional prejudice in these blunders. Many shows against evacuees and Muslims occurred all through the nation.

In the initial nine months of the year, the specialists recorded 813 offences against refuge searchers. In 1803, the experts recorded offences against shelter searchers, of which 254 caused wounds.

The specialists have fizzled refuge searchers. Common society associations kept on detailing instances of oppressive personality checks by the police on individuals from ethnic and religious minorities. In June 2015,the Federal Court dismissed an application for the enlistment of an intersex individual under the third sexual alternative (Schneider, Lang, Pott, 2016).

\section{Corporate Accountability: -}

In August2015, the Dortmund District Court perceived locale in a claim brought by four Pakistani casualties against the German apparel retailer Kik in 2015 and allowed them a lawful guide. September 2012, 260 specialists kicked the bucket and 32 were truly harmed in a fire that annihilated one of Pakistan's biggest material industrial facilities providing Kik (Köppel, 2012).

In December 2015, the legislature embraced a National Action Plan for the execution of the UN rules on the economy and human rights. In any case, the arrangement did not contain satisfactory measures to guarantee 


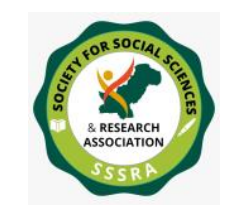

consistency on a fundamental level with every one of the norms set down and did not ensure that German endeavours would submit encroachments in all the principal European nations.

\section{Human Rights Violations in Denmark: -}

In January 2017, the Danish Parliament corrected the Aliens Act, which confines the privilege to family reunification. Those conceding auxiliary assurance statuses must stay cautious for a long time before they can apply for family reunification. In October, four ensured Syrians made a legitimate move against the legislature on the grounds that these progressions damaged their entitlement to family life.

In August, the UN Commission on Human Rights condemned the corrections and communicated worry about another revision to the law presenting the likelihood of reallocating assets of haven searchers as a commitment to the cost of acquiring them.

A similar law additionally contained an arrangement enabling the official to suspend legal survey of the confinement of transients and refuge searchers when the legislature trusted that there had been an extensive convergence of individuals into the nation.

In June, the Danish government presented new confinements on endured remain for people who were barred from assurance as a result of a wrongdoing carried out in Denmark or who believed that they had perpetrated atrocities or non-political violations somewhere else, yet who couldn't be ousted to their nation of cause in view of the genuine danger of human rights infringement (Bronner, 2008).

The legislature has announced its aim to make its stay 'as agonizing as would be prudent'. The new limitations included mandatory convenience at the Kaershoved gard Center around $300 \mathrm{~km}$ from Copenhagen so as to isolate individuals from their Syrian families. People who have abused the "endured stay commitment" have been condemned to detainment in 


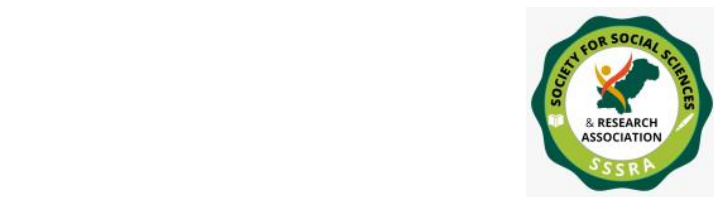

common penitentiaries. Toward the finish of the year, 68 individuals were "endured remain" (Stahnke, et al., 2008).

In October, the legislature postponed the execution of the concurrence with UNHCR on the gathering of 500 exiles from displaced person camps worldwide every year.

- Discrimination in Danish Society:

The systems built up by the Danish Health Service for access to hormone treatment and sex affirmation medical procedure have mistakenly drawn out the procedure of sexual orientation acknowledgement in transgender individuals. The essential tests and polls concentrated on sexual conduct, which numerous transgender individuals discovered embarrassing. Just a single facility was approved to recommend hormonal treatment for transgender individuals.

Toward the finish of the year, the Health Office's procedural rules on sexual orientation balance were changed. In May, Parliament embraced an imaginative determination went for putting a conclusion to the pathology of the transsexual way of life as a psychological issue by the start of 2017 (Copenhagen 2008, May 29)

- Human Rights Violations in Shape of Counter-Terror and Security Measures:-

In August, the UN Human Rights Committee communicated its profound worry about Denmark's over-meaning of psychological warfare in the corrective code and about the police's capacity to capture communication, which could prompt gigantic observation. The Committee approached the administration to completely audit its counter-psychological warfare forces to guarantee consistency with worldwide human rights norms.

Torture and other ill-treatment: - 


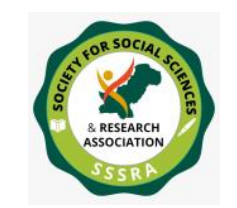

In August, the Supreme Court decided that a common action against the Ministry of Defense against 11 Iraqi residents is permissible. They claim to have been tormented by Iraqi warriors amid a Danish military activity in Basra, Iraq, in 2004. A substantive hearing was planned for 2017. As indicated by these Iraqis, were ruthlessly tormented and harmed numerous individuals amid this task in Basra, Iraq, and fully expecting equity by the Danish Supreme Court (Jakobsen, 2008).

\section{Human Right Abuses in Norway: -}

Human rights infringement was additionally seen in another European nation, Norway. In April2014, the Norwegian Government tabled 40 changes to the Immigration Act to confine access to shelter. This enabled Norway to embrace the "most stringent displaced person approach in Europe". The recommendations gave that the outskirt police and not the migration expert ought to have the ability to evaluate whether a man required international security.

The privilege to family reunification and the privilege ofa refuge for minors have likewise been extremely limited. The most prohibitive components of the bill were not embraced, but rather the bundle received by Parliament in June2014, which went into compelling in August, spoke to a noteworthy advance in reverse in Norway's way to deal with worldwide security.

The New principles accommodate the likelihood for displaced people to apply for a perpetual living arrangement allow so as to demonstrate their monetary autonomy for a time of a year, and in addition for an "emergency component" taking into consideration the ejection to the fringe of a substantial number of refuge searchers touching base on the domain of the nation concerned. 84 kids who had connected for refuge were captured in August, together with a grown-up relative, at the Trandum police confinement focus, close Oslo Gardermoen air terminal, until the point that they came back to their nation of the root (Norwegian Ministry of Foreign Affairs, 2014). 


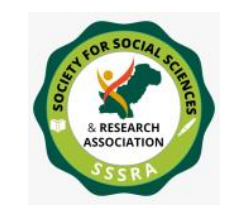

Toward the start of December, 40 youthful Afghans, some of whom were under 18, came back to Afghanistan as a component of the administration's approach to repatriate Afghan refuge searchers.

- Discrimination-transgender, Sex workers: -

In the Norwegian Penal Code, viciousness in view of prejudicial mentalities towards transgender individuals has not yet been delegated a detest wrongdoing. Despite the fact that sex work isn't illicit, ladies who give sexual administrations are as yet subject to elevated amounts of police and endorses. Sexual specialist co-ops have encountered human rights infringement, for example, physical and sexual brutality, including assault, abuse and police.

Upholding enactment on open badgering through sexual work and movement to stop and advance sexual work has prompted the expulsion, police observation, fines, segregation, loss of vocation and extradition of sex specialists. Thusly, transsexuals and sex labors are an obvious objective for their customers and the Norwegian police (Palmstjerna, Haugan, Jarwson, Rasmussen, \& Nøttestad, 2012).

\section{Violence against women and girls in Norway:-}

Rapes and different types of sexual viciousness against women and young ladies are as yet across the board in Norway. There is no compelling reason to favour a lawful meaning of assault in the Penal Code. The variable number of examinations and indictments of assaults and also the absence of affectability of common judges in assault cases keep on raising genuine concerns. Ladies' entitlement to lawful security and correspondence under the watchful eye of the law has not been deliberately ensured. As per police measurements distributed in May 2015, the number of assaults answered to the police expanded by $12 \%$ somewhere in the range of 2001 and 2003. (Young, Klosko, \& Weishaar, 2006). 


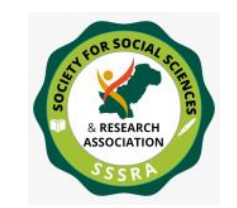

As respects brutality against women and young ladies, human rights issues in Norway were not attractive because of the expanding number of assaults in this part of Europe. As indicated by police reports, the number of assaults answered to the police expanded by $14 \%$ somewhere in the range of 2015 and 2016, and young ladies presented to rape are shrouded by standardized savings in Norway. This is disturbing for the security of women and young ladies in this piece of Europe.

\section{Ban on Performers in UK:-}

In 2017, the celebration recorded a few refusals to issue an abnormal state visa, which pulled in the consideration of the general population and the media. The Iranian kids' author Ehasn Abdollahi at first rejected a choice that had been upset because of political and media weight, and the Austrian vocalist Conchita Werst needed to drop her execution after the individuals from her gathering had been denied visas for the UK. ConchitaWerst performs with Basalt, a trio of Syrian displaced people who fled to Austria after the war started in their country. Werst and his band discharged the video subsequent to dropping the show, in which they clarified (Span, 2016, October 31).

"Tragically, this isn't the main execution at the Edinburgh Festival in 2017 that was dropped because of the refusal to concede a visa to Syrian outcasts.

These cases point to a few conceivably stressing patterns: are individuals denied of visas for a proportionate Muslim celebration? Would it be able to be the Home Office Deliverance (UK Home Office), an occasion for Muslim guests?

- Stressed a Tense Environment in the UK for Muslims Performers:-

These visas had genuine results for Muslims for a few vans and creation organizations, $57 \%$ of those denied visas were compelled to drop the presentation and $85 \%$ said they were compelled to arrange a display with restricted generation and appropriation groups. The coordinators of the 


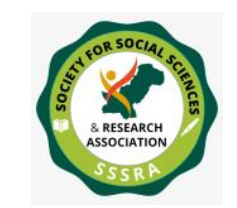

celebration additionally experienced issues in holding settlement for craftsmen because of the deferral in affirming the visa. Higher corporate evaluations are being made.

Bedouin craftsmanship has spent about $\$ 6000$ on issuing visas and has seen an extremely unpleasant and tense condition inside the association since a few people are worried that these issues will influence the program of the celebration later on. One Venue said she would have liked to keep working with "visa-touchy nations yet was worried about the staggering expense of booking such shows later on. Two spots clarified that they were compelled to check the practicality of undertakings with specialists from a few nations, taking note of that "this constrained us to consider conveying Arab craftsmen to the UK in light of the troubles and extra expenses (Elliot, 2017, January 20).

Notwithstanding whether this pattern is expected or not, the mentality of central command towards competitors from Arab nations with a Muslim greater part is amazingly stressing. The effect on the Edinburgh celebration is self-evident, and the pattern is that future celebration programs do exclude Arab or Muslim specialists, who can transform into occasions that lone mirror the workmanship that a few people on the planet bring to the table. This pattern additionally brings up a more extensive issue (Emerson, eds., 2009).

Is the Ministry of the Interior endeavoring to deny a few societies and ethnic gatherings access to the UK as vacationers or something else? Are a few people being denied access to Britain basically on the grounds that they are Muslim? Is this not an infringement of human rights?

\section{Human Right Abuses in Hungary:-}

We have discussed Jobbik's hostile to Semitic and against Roma talk, an outrageous conservative gathering that has not yet quieted down. In fact, Jobbik is more grounded than any time in recent memory, and the shows in Roma urban areas and the require the reintroduction of capital punishment are as yet continuous. A month ago, Jobbik held an exhibition 


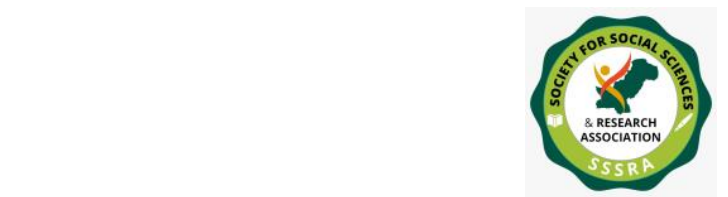

to stamp the 77th commemoration of Laszlo Csatara, Europe's most looked for after war criminal.

He is being held under house catch in Budapest for purportedly running the Nazi internment camp in Košice, Slovakia before the Jews were sent to Auschwitz and other death camps. The compelling loyalist Jobbik won $13 \%$ of the seats in the enthusiastic parliament in 2010, transforming into the third greatest assembling in the country (Anonymous, 2015, April 13). They continue sorting out uncontrolled showings and the facilitators are reprimanded for generous scale bias, which moreover incites ruthlessness. "Biased brutality and acceptance to one-sided violence against all fragments of Hungarian culture should be openly rebuffed and through and through analyzed," said Jazerca Tihani, assign head of Amnesty International in Europe and Central Asia, after a particularly vivacious appearing in the town of Deventer, where most by far of the Roma live.

\section{Human Right Violations in Bulgaria:-}

As one of the fundamental wellsprings of trafficking and people, Bulgaria has not done all things needed to battle composed wrongdoing and human trafficking. The U.S. Division of State's yearly write about trafficking in people infers that, notwithstanding endeavours to end sexual bondage and trafficking, the Bulgarian Government does not completely regard the base guidelines for the disposal of trafficking in individuals.

The European Anti-Trafficking Center perceives that Bulgaria is one of the primary culprits of trafficking in individuals in this field. The universal dissent aggregate FEMEN, which is endeavoring to attract regard for the issue of the trafficking of sexual administrations, sorted out a standout amongst the most essential exhibitions in Sofia in January (Cohen, 2008).

In June, France, Bulgaria, Poland and Belgium made composed move to battle trafficking in individuals in the few EU Member States, however just nine individuals were captured and, as indicated by the Ministry of Foreign Affairs, fewer cases were researched in 2012 by the Bulgarian 


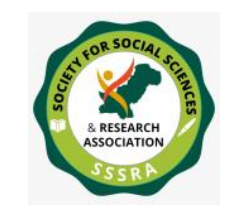

government than in 2011, as indicated by Mathew Yglesias, an American journalist.

"The EU appears have been an imperative power in fortifying majority rule government in 'post-comrade Central Europe', however, numerous individuals don't comprehend why the Union merits a Peace prize, particularly now that such a large number of nations are confronting gravity measures and mass shows. "Peace Prize? What will occur sooner rather than later? Peace is the main thing we can't have," said Giorgos Dertilis, a protection specialist sent to Athens. Notwithstanding human trafficking and trafficking, there are numerous more years to come, for example, drugs and the torment of ladies (Anonymous 2015, May 17).

\section{Conclusion:}

European continent faced manycriticisms by the international community over its human rights violations in EU member countries like UK, France, Italy, Greece, Germany, Romania, Bulgaria, Denmark, Poland, Bosnia and Herzegovina etc. The European Union all in all has not possessed the capacity to demonstrate authority and solidarity notwithstanding the greatest resettlement emergency on the planet since the Second World War. A critical piece of the discussion on the political reactions concentrated on worries about the effect on security and social personality and the developing help for xenophobic projects by populist parties. Tenacious exile emergencies and equipped radical assaults in Belgium, France and Germany have escalated Islamic and hostile to movement feelings, showing themselves in assaults on Muslims, vagrants and outsiders and support for against migrant populist parties in numerous EU nations. In the end, I would conclude this article by mentioning that overcall human rights are being violated in Europe and EU refugee crisis and migrant death are being ignored in this part of the world. 


\section{References}

Amnesty International. (2011). Greece Must Urgently Remedy Deplorable Detention Conditions. Amnesty International Public Statement. https://www.amnesty.org/download/Documents/28000/eur250062011en.p df.

Bronner, L. (2008). Un jeuneproche de l'extrême droite mis enexamen pour uneagressionantimusulmane. le Monde. http://www.lemonde.fr/cgibin/ACHATS/acheter.cgi?offre=ARCHIVES\&type _item=ART_ARCH_3 0J\&objet_id=1047031\&clef=ARC-TRK-G_01

Brunsdon, C. (2005). Feminism, Postfeminism, Martha, Martha, and Nigella. Cinema Journal, 44(2), 110-116.

Bulgaria's Garmen Braces for Massive anti-Roma Protest. (2015, May 17). Society: Novinite.Com: Sofia News Agency. https://www.novinite.com/articles/168825/Bulgaria's+Garmen+Braces+for + Massive+anti-Roma+Protest.

Cohen, E. (2008). Following another Desecration of a Muslim building the institutions remain silent. Bulgarian Helsinki Committee.

https://www.bghelsinki.org/index.php? module $=$ resources \&lg=en\&id=633

Copenhagen (2008, May 29). The Islamic Handscarf in Denmark:Covering up: A far-right party takes on the Islamic headscarf. The Economist. https://www.economist.com/europe/2008/05/29/coveringup.

Council of Europe \& European Court of Human Rights. (2011). Overview of the Court's case-law on freedom of religion. Council of Europe and European Court of Human Rights: Research Division.

https://www.echr.coe.int/Documents/Research_report_religion_ENG.pdf. 
Council of Europe. (2013). Plenary Convention of the Conference of European Rabbis Gala dinner. Council of Europe. Speeches 2013.https://www.coe.int/en/web/secretary-general/speeches-2013thorbjorn-jagland//asset_publisher/gFMvlOSKOUrv/content/plenaryconvention-of-the-conference-of-european-rabbis-galadinner?inheritRedirect=false.

Elliot, P. (2017, January 20). Why Donald Trump's Showmanship Couldn't Save the Inauguration. TIME. https://time.com/4641891/trumpinauguration-event-spectacle/.

Emerson, M. (eds.) (2009). Entho-Religious Conflict in Europe: Typologies Of Radicalisation In Europe's Muslim Communities. http://aei.pitt.edu/32616/1/55._Ethno-Religious_Conflict_in_Europe.pdf.

Emmanuel Tawil. (2005). Strasbourg vu du Palais Royal: Invokation et Reception de la Convention Europeene des Droits de 'homme dans le Traitement Juridique du Voile Islamiqueen France. Strasbourg Concortium.

http://strasbourgconsortium.org/document.php?DocumentID=3877; European Centre for Disease Prevention and Control. (2011). Risk Assessment: Situation in Northern Africa / Libyan Arab Jamahiriya and the Influx of migrants to Europe. https://www.ecdc.europa.eu/en/publications-data/risk-assessmentsituation-northern-africalibyan-arab-jamahiriya-and-influx.

European Comission. (2016, March 19). EU-Turkey Statment: Question and Answers

https://ec.europa.eu/commission/presscorner/detail/en/MEMO_16_963.

Hungary's far-right Jobbik party wins key seat. (2015, April 13). BBC. https://www.bbc.com/news/world-europe-32281713.

Jakobsen, P. V. (2008). NATO's Comprehensive Approach to Crisis Response Operations: a work in slow progress. Danish Institute for International Studies. 


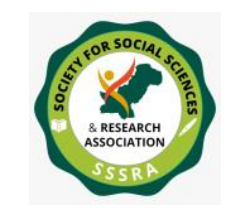

Köppel, P. (2012). Diversity Management in Deutschland 2011: Ein Benchmark unter den DAX 30-Unternehmen. Schwerpunkt:

Unternehmenskultur. www. synergie-durch-vielfalt. delfileadmin/diverse_ PDF/Benchmark_DM_2012.pdf(letzter Zugriff 18.02. 2015).

Martin, M. (2013). Analysis Expulsion of Roma: the French government's broken promise. Statewatch Journal 22(4).

https://www.statewatch.org/media/documents/analyses/no-222-franceroma-expulsion.pdf.

McGoldrick, D. (2006). Human Rights and Religion-The Islamic Headscarf Debate in Europe. Oregon: Hart Publishing.

Mühe, N. (2011). (In-) Tolerance Towards Religious Minorities in German Schools: Religious diversity challenges in regard to Muslim religious practice and education. Final Country Report: European University Institute.

Nisar, M. A. (2006). Manifestation of Religion as Freedom of Expression under European Convention on Human Rights. (Unpublished L.L.M thesis) University of Exeter.

Norwegian Ministry of Foreign Affairs. (2014). Human Rights in Norway's Foreign Policy and Development Cooperation. Meld. Report to the Storting (white paper).

https://www.regjeringen.no/contentassets/261f255d028b42cab91ad099ee3 f99fc/en-gb/pdfs/stm201420150010000engpdfs.pdf..

Ouald Chaib, S. (2013). Suku Phull v. France rewritten from a procedural justice perspective: Taking religious minorities seriously. In Diversity and European human rights: rewriting judgments of the ECHR (pp. 218-240). Cambridge University Press.

Palmstierna, T., Haugan, G., Jarwson, S., Rasmussen, K., \& Nøttestad, J. A. (2012). Cognitive-behaviour group therapy for men voluntary seeking 


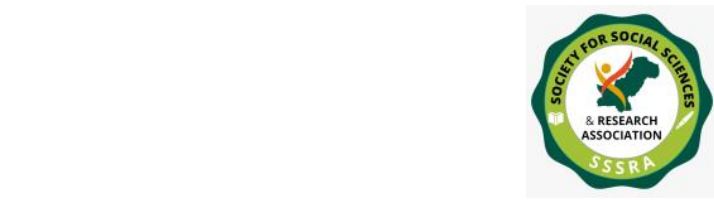

Pak. Journal of Int'L Affairs, Vol 3, Issue 2 (2020)

Fundamental Human Rights Violations...

help for intimate partner violence. Nordic journal of psychiatry, 66(5), 360-365.

Perlez, J. (2007, June 22). Muslims' Veils Test Limits of Britain's Tolerance. The New York Times.

https://www.nytimes.com/2007/06/22/world/europe/22veil.html.

Schneider, J., Lang, C. Pott, A. (2016). Policy Brief. Pathways to Success Erfolgreiche Einwandererkinder und ihre Aufstiegskarrieren im urbanen und internationalen Vergleich. Institutfür Migrations for schung und Interkulturelle Studien (IMIS).

Span, C. (2016, October 31). Road to the White House 2016: Presidential Candidate Donald Trump Rally in Warren, Michigan. https://www.cspan.org/video/?417729-1/donald-trump-campaigns-warren-michigan

Stahnke, T., LeGendre, P., Grekov, I., McClintock, M., Aronowitz, A., \& Petti, V. (2008). Hate Crime Survey. Human Rights

First.[Verkkodokumentti] http://www. humanrightsfirst. org/pdf/FD081103-hate-crimesurvey-2008. Pdf.

The Bureau of Investigative Journalism. (2017, October 9), 'Thousands of British Citizens swept up in immigration spot checks: The Home Office is accused of "racial profiling" by human rights lawyers as MPs call for review. https://www.thebureauinvestigates.com/stories/2017-1009/review-homeoffice-immigration-checks.

Triandafyllidou, A. (2017). The Greek Asylum Crisis: Moving Beyond the blame game to a Real Solution. The Conversation.

https://theconversation.com/the-greek-asylum-crisis-moving-beyond-theblame-game-to-a-real-solution-71107

Vigoureux, C. (2016, November 4). Nouredine Rachedi, "beaten up because he is a Muslim" L'OBS with Rue89.

https://www.nouvelobs.com/rue89/rue89-nos-viesconnectees/20080809.RUE5276/nouredine-rachedi-tabasse-parce-quemusulman.html. 
Yigit, N. (2012). Netzwerk gegen Diskriminierung von Muslimen. In Deutsche Islam Konferenz: Muslimfeindlichkeit-Phänomen und Gegenstrategien. Beiträge der Fachtagung der Deutschen Islam Konferenz am (Vol. 4, pp. 115-117).

Young, J. E., Klosko, J. S., \& Weishaar, M. E. (2006). Schema therapy: A practitioner's guide. New York: Guilford Press.

Zick, A. (2012). Islam- und muslimfeindliche Einstellungen in der Bevölkerung Ein Bericht über Umfrageergebnisse. In Deutsche Islam Konferenz (DIK), Muslimfeindlichkeit-Phänomen und Gegenstrategien. (35-46).Beiträge der Fachtagung der Deutschen Islam Konferenz am 4. und 5. Dezember 2012 in Berlin. bmi.bund.de/SharedDocs/downloads/DE/veroeffentlichungen/themen/hei mat-

integration/dik/tagungsband_muslimfeindlichkeit.pdf?_blob=publication File $\& v=1$ 